\title{
Isolation of Arsenic Oxidizing-reducing Bacteria and Reclamation of As (III) in in vitro Condition
}

\author{
U A Naher ${ }^{1 *}$, F Rahman¹, S M M Islam¹, M I U Sarkar and J C Biswas ${ }^{1}$
}

\begin{abstract}
The study aimed to isolate arsenic (As) oxidizing-reducing bacteria from As contaminated soil and water and to determine their ability to remove As from broth culture. Soil and water samples were collected from As contaminated area of BRRI farm, Bhanga, Faridpur. Arsenic oxidizing and reducing bacteria were isolated from the As contaminated soil $\left(13 \mathrm{mg} \mathrm{kg}^{-1}\right)$ and water $(410 \mu \mathrm{g} / \mathrm{L})$ using spread plate count method in minimal salt (MS) medium after seven days of incubation. The oxidation activity of the bacteria as well as reclamation of As [III] was determined from $\mathrm{NaAsO}_{2}$ supplemented broth using atomic absorption spectrophotometer (AAS). The As-oxidizing bacteria population was present only in one soil sample, while in all water samples both oxidizing and reducing bacteria were present. A total of 36 As oxidizing-reducing bacteria were isolated. As-oxidizing bacteria removed 71-99\% of applied As [III] in broth culture. Two out of 10 As-oxidizing bacterial strains appeared more efficient than others to remove As [III] under broth culture conditions.
\end{abstract}

Keywords: Arsenic oxidizing-reducing bacteria; isolation; reclamation

\section{INTRODUCTION}

Arsenic is a metalloid of global concern due to its toxic and carcinogenic effects. It is widely distributed in the environment due to natural geochemical process and anthropogenic activities (Cullen et al., 1989). Arsenic occurs in nature in four oxidation states $(+5,+3,+2,+1$ and -3$)$. The most common oxidation states of As in the nature are pentavalent arsenate As [V] and trivalent arsenite As [III] and the latter one is more toxic for plant than As [V] (Echrlich, 1996).

In Bangladesh various levels of arsenic contamination were reported in 59 out of 64 districts. Seventy-five million people are at risk and 24 million are potentially exposed to As contamination (MacDonald, 2001 and Malellan, 2002). Thus the removal of As from contaminated environment is necessary for human welfare. The currently available conventional techniques such as precipitation, chemical oxidation and reduction, ion exchange, filtration, reverse osmosis etc for removing heavy metals are found often inappropriate or expensive because of vast polluted area (Chaalaet al., 2005). Therefore, generation of technologies using microorganisms received tremendous attention in the field of bioremediation of heavy metals (Clausen, 2000).

Like many organic contaminants, As cannot be destroyed. It can be immobilized or transformed into less toxic forms. Arsenic bioremediation has already been achieved with As resistant bacteria (Katsoyiannis et al., 2002). A diverse group of heterotrophs are related to As transformation in nature. Arsenic speciation in nature is related to oxidations or reduction by microbes (Oremland et al., 2003). Microbial redox carried out either for detoxification or for energy generation to support cellular growth. In oxidation, microbes convert arsenite As [III] to arsenate As [V] state, which is less toxic to environment. The As [III] oxidation enhances growth of heterotrophic arsenite-oxidizing bacteria and provide sole energy source for chemoautotrophic As-oxidizing bacteria. Moreover, arsenate resistant microbes reduce arsenate [V] to arsenite As [III] (Oremland et al., 2003). Arsenic can be reduced to volatile compounds arsine $\left(\mathrm{AsH}_{3}\right)$ and methyl-arsines. However, the present study aimed to isolate potential As oxidation-reduction bacteria and to determine its capability for detoxification. 


\section{Sample collection}

Arsenic contaminated soil and water samples were collected from Bhanga area of Faridpur district, Bangladesh. Soil samples were preserved in plastic containers and refrigerated until further analysis. Soil used was classified as inceptisol and initial chemical properties were: pH 7.3 (in 1:2.5 water), organic carbon $1.7 \%$, total $\mathrm{N} 0.17 \%$, available P $9 \mathrm{mg} \mathrm{kg}-1$, exchangeable $\mathrm{K} 0.56 \mathrm{cmol} \mathrm{kg}^{-1}$, available S 29 $\mathrm{mg} \mathrm{kg}^{-1}$, and available $\mathrm{Zn} 0.9 \mathrm{mg} \mathrm{kg}^{-1}$. The soil contained $13 \mathrm{mg}$ As per kg.

\section{Isolation of As oxidizing-reducing bacteria}

The isolation was done within seven days after sample collection. One gram of soil samples were taken into $95 \mathrm{ml}$ sterile distilled water and a series of 10 fold dilutions were made up to 108. Exactly $0.1 \mathrm{ml}$ of dilution was spread on each media plate. The As oxidizing-reducing bacterial populations were determined using spread plate count method in minimal salt (MS) medium. Composition of the medium was $\mathrm{NaCl}\left(1.17 \mathrm{~g} \mathrm{~L}^{-1}\right), \mathrm{KCl}\left(0.30 \mathrm{~g} \mathrm{~L}^{-1}\right), \mathrm{NH}_{4} \mathrm{Cl}(0.15 \mathrm{~g}$ $\left.\mathrm{L}^{-1}\right), \mathrm{MgCl}_{2} .6 \mathrm{H}_{2} \mathrm{O}\left(0.41 \mathrm{~g} \mathrm{~L}^{-1}\right), \mathrm{CaCl}_{2}\left(0.11 \mathrm{~g} \mathrm{~L}^{-1}\right)$, $\mathrm{KH}_{2} \mathrm{PO}_{4}\left(0.20 \mathrm{~g} \mathrm{~L}^{-1}\right), \mathrm{Na}_{2} \mathrm{SO}_{4}\left(0.07 \mathrm{~g} \mathrm{~L}^{-1}\right)$ and $\mathrm{NaHCO}_{3}\left(2.00 \mathrm{~g} \mathrm{~L}^{-1}\right), \mathrm{pH}$ 8.0. The MS medium was supplemented separately with $7 \mathrm{ppm}$ of sodium arsenite $\left(\mathrm{NaAsO}_{2}\right)$ for isolation of Asoxidizing and $7 \mathrm{ppm}$ of sodium arsenate $\left(\mathrm{Na}_{2} \mathrm{HAsO}_{4}\right)$ for As-reduction bacteria. After three days of incubation population were counted.

\section{Determination of As transforming ability of the isolated bacteria}

Verification of the transforming ability of the isolate was carried out by using of $\mathrm{AgNO}_{3}$ method.MS media containing $5 \mathrm{mM}$ Na-lactate as carbon source and $5 \mathrm{mM} \mathrm{Na}$-arsenate as the electron acceptor were used to determine the ability of isolates to reduce As [V]. Bacteria were grown under anaerobic conditions and after seven days of incubation at $28^{\circ} \mathrm{C}$, the agar plats were immersed with $0.1 \mathrm{M} \mathrm{AgNO}_{3}$ solution. Reaction of $\mathrm{AgNO}_{3}$ with As [V] or As [III] resulted a coloured precipitate (Simeonova et al., 2004). A brownish precipitate indicates the presence of $\mathrm{Ag}_{3} \mathrm{AsO}_{4}$ (silver arsenate) in the medium while, a yellow precipitate reveals the presence of $\mathrm{AgAsO}_{3}$ (silver arsenite).

\section{Arsenic removal ability of bacterial isolates}

The oxidation activity of the bacteria as well as reclamation of As [III] was determined from $\mathrm{NaAsO}_{2}$ supplemented broth. Exactly, 7000 ppb of $\mathrm{NaAsO}_{2}$ was added to $50 \mathrm{ml}$ of minimal salt broth. After seven days of incubation As [III] was determined using atomic absorption spectrophotometer (AAS) with flow-injection hydride generation system (Model: A Analyst 100 Atomic Absorption Spectrometer, Perkin Elmer).

\section{As oxidizing-reducing bacterial population Initial soil and water As at Bhanga was $13.3 \mathrm{mg}$ $\mathrm{kg}^{-1}$ and $160 \mu \mathrm{g} \mathrm{L}^{-1}$, respectively. The As- oxidizing bacterial population was found only in one soil sample, while in all water samples both bacterial species were present (Table 1). The population of As-reducing bacteria was higher compared to As-oxidizing bacteria. A total of thirty-six As oxidizing-reducing bacteria were isolated and both types can tolerate seven ppm of As. Results of different studies also supported the abundance of As oxidizing-reducing bacteria in the contaminated soil and water (Liao et al., 2011 and Huang et al., 2012).}

Table 1. Population of As oxidizing-reducing bacteria supplemented with seven ppm arsenic

\section{Treatment}

Bacterial population

\begin{tabular}{cc}
\multicolumn{2}{c}{ Bacterial population } \\
\hline As-oxidizer & As-reduction \\
\hline
\end{tabular}

\section{Soil 1}

Soil 2

Soil 3

D1(water)

A3 (water)

A4 (water)

B34 (water) 
Strain verification and reclamation of As [III] invitro condition

The verification of the transforming ability was carried out by using $\mathrm{AgNO}_{3}$ method. The MS agar plates with brownish precipitate revealed the presence of arsenate and activity of arseniteoxidizing bacteria, while the presence of bright yellow precipitation was the activity of Asreducing bacteria.
The As oxidizing bacteria were able to use As [III] for its metabolic activity and consequently decreased about $71-99 \%$ of As [III] in the broth supplemented with $7000 \mathrm{ppb}$ of $\mathrm{NaAsO}_{2}$ after seven days of incubation. Among the tested 10 oxidizers, strain 1 and 2 were found most efficient to use As [III] followed by strain 8 (Table 2). It was found that Pseudomonas putida strain OS-5 completely oxidized $1 \mathrm{mM}$ of As [III] to [V] within 35 hour (Chang et al., 2007).

Table 2. Reclamation of As (III) using As-oxidizing bacteria after seven days of incubation period

\begin{tabular}{lcc}
\hline As oxidizing bacterial strain & As [III] remaining $(\mathrm{ppb})$ & \% reclamation of As [III] \\
\hline As strain 1 & 23.23 & 99.67 \\
As strain 2 & 15.74 & 99.78 \\
As strain 3 & 1301 & 81.41 \\
As strain 4 & 1974 & 71.80 \\
As strain 5 & 1642 & 76.54 \\
As strain 6 & 1902 & 72.83 \\
As strain 7 & 1733 & 75.24 \\
As strain 8 & 387 & 94.47 \\
As strain 9 & 1569 & 77.59 \\
As strain 10 & 1616 & 76.91 \\
\hline
\end{tabular}

A total of 36 As oxidation-reduction bacteria were isolated from Bhanga soil and water samples that can tolerate seven ppm As, either in $\mathrm{NaAsO}_{2}$ or in $\mathrm{Na}_{2} \mathrm{HAsO}_{4}$.Under invitro condition As-oxidizers were able to reduce 71$99 \%$ of As [III] in the broth supplemented with $7000 \mathrm{ppb}$ of $\mathrm{NaAsO}_{2}$ after seven days of incubation. The potential isolated bacterial strains can be used as biofertilizer for removal of As from contaminated soil and water resources.

\section{REFERENCES}

Challal, O, A Y Zekri and R Islam. 2005. Uptake of heavy metals by microorganism: an experimental approach. Energy Sources. 27:87-100.

Chang, Jin-Soo, I-H Yoon and K-W Kim. 2007. Isolation and ars detoxification of arsenic-oxidizing bacteria from abandoned arsenic-contaminated mines. J. Microbiol. Biotechnol. 17(5):812-821.

Clausen, C A. 2000. Isolating metal-tolerant bacteria capable of removing copper, chromium, and arsenic from treated wood.Waste Manage.Res.18:264-268.
Cullen, W R and K J Reimer. 1989. Arsenic speciation in the environment. Chem.Rev. 89:173-764.

Simeonova, D D, D Livermont, F Lagarde, D A E Muller, V L Groudeva and M-C Lett. 2004. Micropltate screening assay for the detection of arsenic-oxidizing and and arsenate reducing bacteria. FEMS Microbiology Letters. 237(2):249-253.

Echrlich, H L. 1996. Geomicrobial interactions with arsenic and antimony.Echrlich H.L. (ed). Geomicrobiology, 3rd ed., New York: Marcel Dekker Inc.pp. 276-293.

Huang, H, Y Jia, G-X Sun and Y-G Zhu. 2012. Arsenic speciation and volatilization from paddy soils amended with different organic matters. Environ. Sci. Technol. 46:2163-2168.

Katsoyiannis, I, A Zouboulis, H Althoff and H Bartel. 2002. As (III) removal from groundwaters using fixedbedupflow bioreactors. Chemosphere.47: 325-332.

Liao, V H-C, Y-J Chu, Y-C Su, S-Y Hsiao, C-C Wei, C-W Liu, C-M Liao, W-C Shen and F-J Chang. 2011. Arseniteoxidizing and arsenate-reducing bacteria associated with arsenic-rich groundwater in Taiwan, J. Contam. Hydrol. 123(1-2): 20-29.

MacDonald, R. 2001. Providing clean water: lesons from Bangladesh.Br Med J. 322:626-627.

McLellan, F. 2002. Arsenic contamination affects millions in Bangladesh. Lancet.359:1127. 